\title{
Comparative Economics of Zero Budget Natural Farming with Conventional Farming Systems in Northern Dry Zone (Zone-3) of Karnataka
}

\author{
Babalad, H.B. ${ }^{1}$, Gunabhagya ${ }^{2 *}$, Saraswathi ${ }^{2}$ and Gurudevi V. Navali ${ }^{2}$ \\ ${ }^{1}$ University Librarian and Principle Investigator of NF project, University of Agricultural Sciences, Dharwad, College of Agriculture \\ Vijayapura, Karnataka, India \\ ${ }^{2}$ Research Associate, ZBNF Zone-03, College of Agriculture Vijayapura, University of Agricultural Sciences, Dharwad, Karnataka, \\ India
}

*Corresponding author: guna811@gmail.com (ORCID ID: 0000-0002-3775-2965)

Received: $17-02-2021$

Revised: 22-04-2021

Accepted: 26-05-2021

\begin{abstract}
The present study was initiated during 2019-20 to illustrate the comparison between zero budget natural farming and conventional farming systems in terms of the economics of selected major crops cultivated under ZBNF system in the Northern Dry Zone of Karnataka. In order to identify main differences between natural and conventional farming practices, descriptive statistics have been used to analyze the primary data collected from 80 farmers across the 8 districts of the northern dry zone of Karnataka. The study was planned to highlight the main characteristics of those two systems to address the differences in cost and returns. The results revealed that the total cost under ZBNF was observed to be lower than the conventional farming system. The average yield realized under ZBNF system was slightly lower than a conventional farming system in all the crops except foxtail millet. This is clearly indicated that the ZBNF system was performed well in millets cultivation under the rainfed situation. And around 92 percent of the farmers experienced that, the cost of cultivation under ZBNF was minimized. Further, the study highlighted a statistically significant difference between ZBNF and conventional yield levels, cost of cultivation, and income at multiple locations. According to the 'farmer's opinion, most farmers opined that the pest and disease were unable to manage in ZBNF.
\end{abstract}

\section{Highlights}

(0 The zero budget natural farming recorded a significantly lower cost of cultivation than the conventional farming system, and millets cultivation is well responding under the ZBNF system.

Keywords: Comparative economics, conventional farming, Mann-Whitney U Test, zero budget natural farming

Agriculture is the most crucial sector of 'India's economy, contributing nearly 19.9 percent of total GDP during 2020-21. Despite a sturdy decline in the contribution of agriculture to GDP over the past decade, it is still the single most significant contributor to the GDP. It plays an imperative role in the overall socioeconomic development of the farming community in the country. Cultivation of crop, being the primary sector of India, is involved in sustaining livelihood and providing employment opportunities for most of the Indian population.

About 41.49 percent of the total labor force is still getting employed in the farming sector, which has made, more than half of the Indian population

\footnotetext{
How to cite this article: Babalad, H.B., Gunabhagya, Saraswathi and Navali, V.G. (2021). Comparative Economics of Zero Budget Natural Farming with Conventional Farming Systems in Northern Dry Zone (Zone-3) of Karnataka. Economic Affairs, 66(2): 355-361.
} 
dependent on agriculture for their livelihood (NSSO, 2020), but their share in the GDP is insignificant, as compared with what labor received in industry and services. Moreover, the crop productivity is also stagnant in many crops when compared internationally due to low and uneconomical input usage, inefficient agricultural extension efforts affecting access to modern technology for cultivators. Apart from this, even though the emergence of several price stabilizing policies, farmers cannot benefit from minimum support prices (MSP) due to limited procurement operations. Hence, farmers are thinking that farming is not a profitable venture in recent days because of fragmented land holding, scarcity of agricultural labors during peak season is inducing farmers to migrate urban areas and engage in non-farming activities like construction for better and continuous returns and employment throughout the year.

During the past development period, agricultural policy in the country has been given more importance to ensure food security, and farmers also agreed to fulfill the 'nation's needs and adopted all green revolution technologies into crop cultivation. Whileive the country realized admirable position in food production, unfortunately, farming itself turned non-profitable overtime due to intensifying production costs, reduced soil fertility due to excessive use of chemical fertilizers, and pesticides at the cost of minimal use of organic fertilizers manure. The 'farmers' distress condition in the recent past across the country has upset the agrarian foundations and policymakers. To overcome to enhance the ill effects of green revolution on soil fertility, and enhance farming community income by ensuring their income security, thus, has been of present and foremost concern to all the policymakers and cultivators. Until and unless farming community income levels increase substantially, distress cannot be overcome (Chand, 2016).

Increasing the gross income, reducing the costs, and stabilizing several possibilities are available to stabilize the farmers' income, increase the gross income, reduce the costs, and stabilize the costs and stabilizing income. A few among various approaches to enhance 'farmers' income and soil fertility are organic farming, natural farming, low external input sustainable agriculture, precision farming, etc, which are being promoted over time to reduce chemical use and cost of production.

Presently, the cost of cultivation has been rising, reducing the farm profits. Lowering the cost of cultivation without compromising the output can increase the farming income. Furthermore, it is possible to do so as there is a general tendency of farmers to use overdoses of inputs, especially chemical fertilizers and pesticides, expecting higher productivity. In order to overcome the crisis, among all the possibilities, Zero Budget Natural Farming (ZBNF) is the current concern to all the scientists, policymakers, and consumers in Karnataka state to reduce costs on excessive use of chemical fertilizers, pesticides and to grow healthy food.

Zero Budget Natural Farming, as the name indicates, is a farming method where the cost of growing and harvesting crop is minimum. This means farmers need not purchase external inputs like chemical fertilizers and pesticides to grow food. The key objective of the ZBNF is to improve soil fertility and to protect the environment. ZBNF is a low-input, low--risk farming practice and a climate resilient model that-risk farming practice and a climate resilient model that-risk farming practice and a climate-resilient model that-risk farming practice and a climate-resilient model-risk farming practice and a climate-resilient model in harmony with nature. It is a complete the, shift model from high external input base conventional farming evolved during the green revolution and shift model from high external input base conventional farming evolved during the green revolution and from expensive organic input-based agriculture farming.

In recent decades, many of the Indian states are adopted ZBNF system and realized its importance in maintaining soil bio-life and in 'farmers' income (APZBNF, 2018). With this knowledge, Zero Budget Natural Farming (ZBNF) is being proposed in Karnataka for the first time under the state scheme. Karnataka State Department of Agriculture is the nodal department for the implementation of the scheme. In the first phase, it is proposed to implement the scheme on a pilot basis in all the 10 Agro-Climatic zones of the state thorough concerned State Agriculture/Horticulture Universities to undertake demonstrations in 'farmer's fields to validate the ZBNF practices. Keeping the -said facts in view, the present study was initiated to analyze 
the status of comparative economics of ZBNF and conventional farming systems in the northern dry zone of Karnataka.

\section{MATERIALS AND METHODS}

The study was undertaken in the Northern Dry Zone of Karnataka (Zone-3), which comprises eight districts, viz., Vijayapura, Bagalkote, Belagavi, Bellary, Gadag, Koppal, Raichur, and Dharwad, during the year 2018-19. To compare the economics of two farming systems, necessary primary data relating to labor use pattern, input use pattern and its costs composition, return structures were collected. The simple random sampling method was used for the selection of the farmers. From each of the selected districts, 10 farmers practicing ZBNF and conventional practices in each crop that is predominantly grown under the ZBNF system were selected from the district to analyze the cost and returns. Hence, the total sample size was 80 . The relevant primary data was collected from farmers with the help of various monitoring teams appointed by the state agriculture department and concerned agriculture universities. 2-3 villages together make a cluster which is additionally supported by an agriculture officer as a nodal officer, a Community Assistant (CA), and Community Resource Persons (CRPs), including one subject wise Research Associates (RAs). CRPs are residents who may be regarded as 'information 'disseminators' to ZBNF farmers, implementing all aspects of ZBNF, who play a leading role in promoting farmer-to-farmer learning and acting as a bridge between farmers and subject matter specialists. Research Associates are acting as subject matter specialists who are involved in observing and collecting field samples personally from ZBNF beneficiary 'farmer's field. Regular monitoring of CRPs and CAs in the farmers' field made us to get accurate data on ZBNF. Moreover, selected farmers were regularly monitored to provide required information on method of preparation of ZBNF components and their timely and efficient application.

The collected data was analyzed by using descriptive statistical analysis and the Mann-whitney $U$ test. All the selected crops were annual crops with an approximate economic bearing life span of 6-12 months. Standard cost concepts were used to analyze the cost of cultivation. The gross income was calculated by multiplying the quantity of the main product to its prices realized by the farmers. In order to know the significant difference between the yield, cost of cultivation, gross returns, and net returns across the sample a -non-parametric test viz., Mann-Whitney $U$ test was employed. This test is used to compare the difference between two independent groups with the flowing procedure.

The test statistic for the Mann Whitney $U$ Test is denoted $U$ and is the smaller of $U_{1}$ and $U_{2^{\prime}}$ defined below.

$$
\begin{aligned}
& U_{1}=n_{1} n_{2}+n_{1}\left(n_{1}+1\right) / 2-\sum R_{1} \\
& U_{2}=n_{1} n_{2}+n_{2}\left(n_{2}+1\right) / 2-\sum R_{2}
\end{aligned}
$$

Where,

$n_{1}$ is the total sample size of the ZBNF farmers

$n_{2}$ is the total sample size of the conventional farmers (80 pairs)

$R_{1}=$ sum of the ranks for ZBNF group and $R_{2}=$ sum of the ranks for the conventional group.

To get accurate results, the data was cleaned and analyzed by using IBM SPSS Statistics. These data cover rainfed and irrigated cereal, pulse, millet crops, and sugarcane as cash crops. Across all 8 districts Zone-3 of Karnataka state. To facilitate paired comparison of yields between ZBNF and conventional farming conditions, crop cutting experiments $(5 \times 5 \mathrm{~m})$ were conducted in all the ZBNF sample farmer fields. The conventional farming samples were taken from a section of a ZBNF 'farmers' field where conventional practices were being used or hardly if the farmer total landholding was less than one hectare then, an adjacent field where the same crop was being cultivated using conventional practices was considered for the study.

\section{RESULTS AND DISCUSSION}

A total of 10 farmers practicing ZBNF and conventional practices in major crops across the districts were selected for the study and classified as rainfed and irrigated crops. Rainfed crops included red gram, foxtail millet, bajra, chili, and irrigated crops are sugarcane and paddy. The observations on yield, cost, and returns were recorded for the major crops of zone- 3 districts and presented in Table 1 . 
Table 1: District wise economic analysis of different crops under ZBNF and conventional farming practices (2019-20) ( $\mathrm{n}=10$ from each crop)

\begin{tabular}{|c|c|c|c|c|c|c|c|c|c|c|}
\hline \multirow{2}{*}{$\begin{array}{l}\text { Sl. } \\
\text { No. }\end{array}$} & \multirow{2}{*}{$\begin{array}{l}\text { Name of } \\
\text { Districts }\end{array}$} & \multirow{2}{*}{ Crop } & \multicolumn{2}{|c|}{ Yield (q/ha.) } & \multicolumn{2}{|c|}{ Gross Returns (₹/ha) } & \multicolumn{2}{|c|}{ Net Returns (₹/ha) } & \multicolumn{2}{|r|}{ B:C Ratio } \\
\hline & & & ZBNF & Conventional & ZBNF & Conventional & ZBNF & Conventional & ZBNF & Conventional \\
\hline 1 & Vijayapura & Redgram & 5.83 & 8.75 & 27984 & 42000 & 11654 & 16550 & 1.72 & 1.68 \\
\hline 2 & Belagavi & Sugarcane* & 86.00 & 96.20 & 245100 & 274170 & 145900 & 171870 & 2.48 & 2.69 \\
\hline 3 & Bagalkote & Sugarcane* & 77.50 & 80.30 & 220875 & 228855 & 132975 & 125955 & 2.52 & 2.24 \\
\hline 4 & Bellary & Foxtail millet & 16.95 & 15.80 & 30510 & 28440 & 19899 & 17151 & 1.87 & 1.60 \\
\hline 5 & Koppal & Bajra & 15.10 & 15.45 & 36240 & 37080 & 21940 & 20330 & 2.54 & 2.22 \\
\hline 6 & Gadag & Onion & 98.80 & 125.00 & 59280 & 75000 & 18880 & 22250 & 1.46 & 1.42 \\
\hline 7 & Raichur & Paddy & 56.90 & 81.60 & 125180 & 179520 & 79430 & 114070 & 2.73 & 2.76 \\
\hline 8 & Dharwad & Chilli & 6.55 & 8.55 & 65500 & 85500 & 19050 & 26650 & 1.43 & 1.48 \\
\hline
\end{tabular}

Cont.,

\begin{tabular}{|c|c|c|c|c|c|c|c|c|c|c|}
\hline \multirow{2}{*}{$\begin{array}{l}\text { Sl. } \\
\text { No. }\end{array}$} & \multirow{2}{*}{$\begin{array}{l}\text { Name of } \\
\text { Districts }\end{array}$} & \multirow[t]{2}{*}{ Crop } & \multicolumn{2}{|c|}{$\begin{array}{c}\text { Labour Cost } \\
\text { (₹/ha) }\end{array}$} & \multicolumn{2}{|c|}{$\begin{array}{c}\text { Input/ Material Cost } \\
(₹ / \mathrm{ha})\end{array}$} & \multicolumn{2}{|c|}{$\begin{array}{c}\text { Cost of cultivation } \\
\text { (₹/ha) }\end{array}$} & \multicolumn{2}{|c|}{$\begin{array}{c}\text { Cost of production } \\
(₹ / q)\end{array}$} \\
\hline & & & ZBNF & Conventional & ZBNF & Conventional & ZBNF & Conventional & ZBNF & F Conventional \\
\hline 1 & Vijayapura & Redgram & 8950 & 10800 & 7380 & 14650 & 16330 & 25450 & 2817 & 2923 \\
\hline 2 & Belagavi & Sugarcane* & 51500 & 44200 & 47700 & 58100 & 99200 & 102300 & 1160 & 1066 \\
\hline 3 & Bagalkote & Sugarcane* & 48700 & 44800 & 39200 & 58100 & 87900 & 102900 & 1136 & 1287 \\
\hline 4 & Bellary & Foxtail millet & 5420 & 5450 & 5180 & 5475 & 10611 & 10925 & 631 & 693 \\
\hline 5 & Koppal & Bajra & 8550 & 7150 & 5750 & 9600 & 14300 & 16750 & 949 & 1092 \\
\hline 6 & Gadag & Onion & 17850 & 23150 & 22550 & 29600 & 40400 & 52750 & 412 & 424 \\
\hline 7 & Raichur & Paddy & 25700 & 28750 & 20050 & 36700 & 45750 & 65450 & 845 & 806 \\
\hline 8 & Dharwad & Chilli & 26300 & 25150 & 20150 & 33700 & 46450 & 58850 & 7311 & 6924 \\
\hline
\end{tabular}

Note: Fixed costs are excluded from cost of cultivation; ${ }^{*}=$ yield in tonnes.

\section{Economics of crops cultivated under rainfed condition}

Redgram is the primary crop of the Vijayapura district, which is predominantly cultivated under ZBNF system in the district. Ten ZBNF farmers and conventional farmers were selected for further study. The results revealed that a higher average yield was recorded in conventional farming $(0.87 \mathrm{t} /$ ha) as compared to ZBNF (0.53t/ha). On the other hand, the cost of cultivation per hectare was 35.83 percent ( $₹$ 16330/ha) lower in ZBNF as compared to conventional farming ( $₹ 25450 /$ ha); hence the benefit-cost ratio was higher in ZNBF.

The millets and cereals responded well in the natural farming system as it requires low external inputs. Under a rainfed situation, foxtail millet gives sustainable yield levels; hence foxtail millet is a major crop grown by the farmers in the Bellary district under ZBNF system. It is observed from the results that the average yield (1.6/ha) and benefit-cost ratio were higher in the case of ZBNF as compared to a conventional farming system (1.58t/ha). However, the bajra yield did not differ much among the farming systems. In bajra, the cost of cultivation and -cost ratio in both systems was similar as the crop requirefewer external inputs.

Onion and chili was the primary commercial crop, predominantly grown under ZBNF in Gadag and Dharwad district. In the case of onion and chili, the higher yield was recorded under the conventional farming system (125q/ha and 8.55q/ ha, respectively) as compared to ZBNF (9.88t/ha and $0.65 \mathrm{t} / \mathrm{ha}$, respectively). The cost of cultivation under ZBNF was 23.41 percent (₹ 40400/ha) lower than a conventional farming system (₹ 52750/ha). The net returns and benefit-cost ratio in chili cultivation did not differ as production cost is lower in the ZBNF system. 


\section{Economics of crops cultivated under irrigated condition}

Sugarcane is an important commercial crop of the state. During 2018-19, it was grown in an area of 4.95 lakh hectares with annual cultivation of 423.23 lakh tonnes. The average productivity of the crop was 85.34 tonnes per hectare (Source: Directorate of Economics \& Statistics-2018-19). The major sugarcane growing districts in zone-3 were Belgaum and Bagalkote because of the availability of assured irrigation. It was noticed from the results that the average yield realized under ZBNF was significantly higher in Belagavi district (86 t/ha) as compared to the Bagalkote district (77.5 t/ha). The average yield obtained in the region was 92.15 tons per hectare under conventional cultivation during 2018-19, which is relatively more significant productivity per hectare than ZBNF cultivation. The significant variety growing by the farmers was Co86032. The cost and return analysis of sugarcane in irrigated conditions under ZBNF was done in Belagavi and Bagalkot district. Overall, per hectare total cost of cultivation of sugarcane under ZBNF was worked out to be ₹ 99, 200. Labour and input costs accounted for 51.91 and 48.08 percent of the total cost, respectively in Belagavi district. The total cost of sugarcane cultivation under ZBNF in Bagalkot district was recorded as ₹ 87,900 of which 55.40 percent comprised labor cost and 44.59 percent as input cost. The cost under ZBNF system was significantly lower than conventional farming, mainly due to eliminated application of costly chemical fertilizers and herbicides.

The two taluks of the Raichur district covered under zone-3 jurisdiction are Sindhanur and Lingasugur. Paddy is the major crop cultivated under ZBNF in the district; hence paddy was selected for the study. There was 30.26 percent reduction in yield was noticed under ZBNF (56.90q/ha). To compared to the conventional farming system $(81.6 \mathrm{q} / \mathrm{ha})$, and there was no significant difference in the benefit-cost ratio. The cost of cultivation was reduced as high as 30.09 per cent in ZBNF ( $₹ 45750 /$ ha) as compared to a conventional farming system (₹ 65450/ha).

Considering the performance of the crops in terms of cost of cultivation, gross returns and net return generated, it can be noticed that, the cultivation of crops under ZBNF was an economically viable activity. The study conducted by Bharucha et al. (2020) in Andhra Pradesh reported higher yields from ZBNF fields than conventional fields. However, the present study results were in the opposite manner, where ZBNF yields were lower than conventional yield. The increase or decrease in yields with adopting any new technology is not a similar in all the locations. However, it depends on how crops have been produced in the conventional system and other factors such as soil condition and timely availability of nutrients from the components applied in the system, etc. For instance, Birzer and Badgery (2006) found in a survey of organic wheat farmers across five Australian states that, farmers who produced conventionally in the initial year noted a decline in yields; however, after the fourth year, yields showed improvements; whereas, farmers who already used organic methods since from 3-4 years did not see a decrease in yields, in the present study also the yield levels under ZBNF will increase after 3-4 years of the conversion period.

Table 2: Mann-Whitney U Tests for difference in yields, cost of cultivation and income between ZBNF and conventional farming across the districts in rainfed and irrigated crops ( $\mathrm{n}=80$ pairs)

\begin{tabular}{|c|c|c|c|}
\hline \multirow{2}{*}{$\begin{array}{l}\text { Sl. } \\
\text { No. }\end{array}$} & \multirow[b]{2}{*}{ Particulars } & \multicolumn{2}{|c|}{ Significance P-value } \\
\hline & & $\begin{array}{l}\text { Rainfed } \\
\text { crops }\end{array}$ & $\begin{array}{l}\text { Irrigated } \\
\text { crops }\end{array}$ \\
\hline 1 & Yield (tons./ha) & $0.029 *$ & $0.001^{* *}$ \\
\hline 2 & Cost of cultivation ( $(₹ / h a)$ & $0.001^{* *}$ & $0.014^{*}$ \\
\hline 3 & Gross Income (₹/ha) & $0.012^{*}$ & $0.045^{*}$ \\
\hline 4 & Net return (₹/ha) & $0.041^{*}$ & $0.176^{\mathrm{NS}}$ \\
\hline
\end{tabular}

Note: ${ }^{*}$ significant $p<0.05,{ }^{* *}$ significant at $p<0.01$.

The results revealed a statistically significant difference between ZBNF and conventional crop yield. Mann-Whitney U Test was analyzed for rainfed and irrigated crops to make out the overall significance. It was confirmed from the table 2, that the yield, cost of cultivation, gross returns, and net returns was significant at 5 percent of the probability level. The yield, cost of cultivation, and gross returns realized under irrigated conditions was significantly differed among ZBNF and conventional farming and were significant at 1 and 5 percent of the probability level. However, the net returns realized in the crops cultivated under irrigation condition was statistically -non-significant. It is essential to notice that the lower yield realized 
under ZBNF system in all the crops was may be due to the initial period of conversion. Also, it is interesting to note that the cost of cultivation under ZBNF system was significantly lower as compared to conventional farming, which is due to avoidance of the application of costly synthetic fertilizers and pesticides; hence, overall net returns realized was higher in case of ZBNF system as compared to conventional farming.

\section{Opinion of the sample farmers}

The opinion survey was conducted to realize the efficiency of ZBNF system after the harvest of crops, and results are presented in Table 3.

Table 3: Efficiency of natural farming practices according to 'farmer's general opinion $(n=60)$

\begin{tabular}{|c|c|c|c|c|}
\hline \multirow{2}{*}{$\begin{array}{l}\text { Sl. } \\
\text { No. }\end{array}$} & \multirow{2}{*}{ Particulars } & \multicolumn{3}{|c|}{$\begin{array}{l}\text { Per cent to total no. } \\
\text { of farmers }\end{array}$} \\
\hline & & Yes & No & $\begin{array}{l}\text { No } \\
\text { change }\end{array}$ \\
\hline 1 & $\begin{array}{l}\text { Pest management thorough } \\
\text { ZBNF components }\end{array}$ & 7.51 & 89.23 & 3.26 \\
\hline 2 & $\begin{array}{l}\text { Diseases management thorough } \\
\text { ZBNF components }\end{array}$ & 11.52 & 78.36 & 10.12 \\
\hline 3 & Higher requirement labour & 46.23 & 51.26 & 2.51 \\
\hline 4 & $\begin{array}{l}\text { Improvements in soil } \\
\text { parameters }\end{array}$ & 0 & 18.95 & 81.05 \\
\hline 5 & $\begin{array}{l}\text { Improvement in population of } \\
\text { soil arthropods }\end{array}$ & 0 & 22.54 & 77.46 \\
\hline 6 & $\begin{array}{l}\text { Availability of Assured } \\
\text { marketing for ZBNF produce }\end{array}$ & 0.25 & 12.36 & 87.39 \\
\hline 7 & Improvements in yield levels & 33.71 & 54.13 & 12.16 \\
\hline 8 & $\begin{array}{l}\text { Received higher market price } \\
\text { for ZBNF output }\end{array}$ & 2.36 & 64.21 & 33.43 \\
\hline 9 & Reduction in cost of cultivation & 92.03 & 1.21 & 6.76 \\
\hline 10 & $\begin{array}{l}\text { Higher credit requirement in } \\
\text { ZBNF }\end{array}$ & 0.81 & 62.3 & 36.89 \\
\hline
\end{tabular}

Among all the farmers, around 89 and 78 percent of the farmers opined that the incidence of pest and disease in field crops were not managed effectively under ZBNF by using natural farming plant protection formulations like neemastra, brahmastra and agniastra; hence, the yield and quality of the grains was reduced. Further, 51 percent of the sample farmers expressed that the requirement of labor was more in case of ZBNF, and around 46 percent were opined the lower requirements of labours. On the other hand, 81 and 77 percent of the farmers indicated that none of the changes occurred in soil parameters and that none of the changes occurred in soil parameters and soil in arthropods population, respectively. Concerning crop yield levels, 54 per cent of the sample farmers experienced lower yields, 34 per cent opined higher in yield levels, and the rest of the farmers experienced no change in yield between ZBNF and conventional practice. The market price obtained per unit was influenced by crop sales and the growth of grains proved to be a crucial variable in the crop economics (Shah, 2005). In the present study, price per unit was less in ZBNF output, which was opined by 64 percent of the respondents. Around 92 percent of the farmers felt that the cost of cultivation under ZBNF was lower than conventional farming systems; hence, the requirement of credit was also minimized. The present study result was on par with the study conducted by Khadse et al. (2017).

\section{CONCLUSION}

The study results revealed that the cost of cultivation under ZBNF was observed to be lowest compared to the conventional farming system because the cost of external inputs under ZBNF was significantly lower due to recycling farm of resources. On the other hand, the average yield realized under the ZBNF system was slightly lower than the conventional farming system in all the crops except foxtail millet; the ZBNF system indicates this was performed well in millets cultivation under a rainfed situation. Hence this system needs to be promoting among millets growing farmers across the state to get higher income. Moreover, if the farmers carried out the cultivation for more than three years under the ZBNF system, they should get different premium prices for their produce concerning ecology and environmental conservation. Further, it needs relevant research and extension services to identify the natural environmental, social, and health externalities under the ZBNF system.

\section{REFERENCES}

APZBNF, 2018. Zero budget natural farming. Http://Apzbnf. in/Faq/. http://apzbnf.in/faq/. Accessed 20 Sept. 2020.

Birzer, T. and Badgery, W. 2006. Organic Wheat Farming in Australia: Issues farmers face. AFBM J. Farm Bus. Farm. Syst. Manag., 3(2): 8-21. 
Chand, R. 2016. Addressing Agrarian Distress: Sops versus Development, B.P. Pal Memorial Lecture, Discussion paper, Indian Agricultural Research Institute, New Delhi.

Khadse, A.P., Rosset, H. Morales and Ferguson, B.G. 2017. Taking agro-ecology to scale: The Zero Budget Natural Farming peasant movement in Karnataka, India. J. Peasant Stud., 41(4): 1-28.
NSSO. 2020. Key indicators of situation of agricultural households in India. National Sample Survey Office, Government of India.

Shah, T. 2005. Social Impact of Technical Innovations. Study of Organic Cotton and Low Cost Drip Irrigation in the Agrarian Economy of West Nimar Region, at www.fibl. org. Accessed $1^{\text {st }}$ Nov 2020. 
